\title{
Thinking Anthropologically for the Theologically and Missiologically Engaged
}

\author{
Johannes Merz
}

\begin{abstract}
The attitude and ability to think anthropologically is both the most basic and most sophisticated aspect of contemporary anthropology. Thinking anthropologically is putting humans at the center by asking what it is to be human in different places and relationships, and in how we engage with the world around us. Thinking anthropologically is keeping human commonality and cultural and social diversity in balance. Thinking anthropologically is learning to be reflexive by thinking about ourselves and others, as well as thinking about the way we think. Thinking anthropologically is a great asset whenever we are faced with other humans, and thus provides the starting point for those who are theologically and missiologically engaged by providing a basis for all anthropological, theological and missiological reflection and activity.
\end{abstract}

\section{Introduction}

Anthropology, or the study of humanity, "is first and foremost a way of thinking that can be applied to any aspect of human life" (Eriksen 2010, 194). And yet, anthropology remains an obscure, abstract and often poorly understood academic discipline to the extent that few see value in engaging with it (Eriksen 2006). Especially in Christian circles some even see it as a threat due to its supposed anti-religious bias (Arnold 2006; Larsen 2014; Merz and Merz 2017). Since anthropology concerns humans, however, its underlying way of thinking is relevant for anyone who deals with people, including those who engage in theology and missiology.

In this article I draw on contemporary anthropology to explain how thinking anthropologically underpins our engagements with other humans. Anthropology is important wherever humans meet and collaborate, especially when they come from different cultural and social backgrounds. Not everybody needs to become an anthropologist with all the ins and outs of the discipline, but I propose that everyone who works with fellow humans benefits from thinking anthropologically. The questions I address in this article are: what it is to think anthropologically, why this is important, and how we can better apply this ability to our lives and work as we engage in theology and missiology.

To think anthropologically is to put humans at the center of our thinking. It begins with the recognition that we all share a common humanity, while at the same time humans demonstrate an immense diversity. Learning to think anthropologically necessitates learning about and applying anthropological methods. The most important method is reflexivity, which entails learning not only to think about others, but also about ourselves.

When it comes to God, anthropology has typically tried to rationalize the more religious and spiritual aspects of humanity as purely social phenomena, thus neglecting and sometimes actively negating the idea of any kind of spiritual agency. Theology, on the other hand, deals more aptly with such questions while accepting them as valid in their own right, thus complementing anthropology in these areas. A theologically engaged anthropology, then, not only contributes to thinking anthropologically, but also informs missiology, which is about how we apply anthropology and theology to serve others.

In summary, thinking anthropologically is above all an attitude and ability that we can learn by drawing mainly on anthropology, but also on theology. Thinking anthropologically should provide the starting point for missiological reflection and practice. So, let us start by looking at what it means to think anthropologically.

\section{Thinking Anthropologically}

Anthropology, broadly speaking, is the study of humanity. In current cultural and social anthropology, 
especially in its ontological ${ }^{1}$ orientation, the most basic question we ask is what it is to be human in different places and relationships, and how we engage with the world around us. Anthropologists do this by focusing on cultural and social differences that exist among humans. They have developed methods and theories that help us to learn not only about those who are different from us, but also about ourselves, or, in other words, to think anthropologically.

Many professional anthropologists would agree that although engaging with anthropology can be challenging, it has many positive effects: Anthropology opens our minds to human difference and allows us to recognize that how we think, act, and live in our world does not provide the norm that everybody else should follow. Rather, anthropology helps us to appreciate the sheer cultural and social diversity we find among humans in today's world. It helps us to understand better such diversity by studying different people with specific cultural and social backgrounds. This, in turn, helps us to recognize the value of different ways of living. Anthropology should thus transform our view of difference, which we sometimes experience as fear and a threat, into a valuable resource of deepening our understanding not only of our counterparts, but also of ourselves and of what it is to be human more broadly. In other words, engaging with anthropology is much more than practicing an academic discipline and applying a set of methods, it is also a way of thinking. Engaging with anthropology should allow us to think more and more anthropologically, change some of our attitudes, and affect the way we think, act, and live.

Having said this, academic anthropologists do not have, and cannot claim, a monopoly on thinking anthropologically. Rather, I like to think of academic anthropology as the backbone of the domain, while the ability to think anthropologically is both more fundamental and broader and thus the flesh and blood. There are many other practical things we can do that contribute to acquiring such a skill and attitude. To name a few, they include learning another language, opening up our home to neighbors who have different cultural or social backgrounds, travelling abroad with an open mind, watching movies from other parts of the world, or reading accounts written by travel writers who reflect on issues of cultural and social difference. While we may not always need anthropology to do well in such areas, the discipline is very aptly positioned to guide and give input into learning how to think anthropologically, and provides a more systematic and thorough way of doing so. Engaging with anthropology can thus speed up our learning process, as it helps us to engage with our counterparts more efficiently and/or effectively. This, in turn, can help us to figure things out that we find puzzling and to learn about important issues that we may otherwise overlook. More positively, anthropology can add to the quality of life and work as we seek to live and engage with those who surround us, however similar or different they appear to us.

So, the question is, what do I mean by thinking anthropologically? How can we begin to think anthropologically more purposefully? What can we do practically, as we seek to accustom ourselves to thinking anthropologically?

\section{Human Commonality and Diversity}

Thinking anthropologically always centers on and around humans. In whatever we do in life and work, we start with ourselves as humans and we rely on other humans in many ways as we live and engage with other humans. There are two crucial aspects to being human that anthropology as the study of humanity has established. We all share a common humanity, while at the same time we equally can observe the sheer diversity in how humans live their lives across the world. While anthropologists often focus on human diversity, such diversity necessarily builds on our shared humanity, which is perhaps the most basic and most crucial assumption and even condition of doing anthropology (Bowman 1997; Larsen and King 2018).

Recent advances in biological anthropology stress that the physical differences we sometimes notice among ourselves are so minor that "biologically speaking, race is a myth" (Engelke 2018, 169). It is therefore not justified to talk about races or subspecies when it comes to humans. This means that all contemporary humans, wherever we have been born and raised, have the disposition to live, survive and even thrive anywhere where there are other humans.

There is much more to humans than biology, however, since humans also share cultural, social, linguistic, psychological and spiritual needs and abilities that facilitate our capacity to adapt to very different environments. This, in turn, results in the cultural and social differences and diversity we encounter. In practice, this means that even though we share a common humanity it is not always easy to understand and cope with the differences and diversity of our counterparts. This is where the cultural and social sides of humanity typically addressed by anthropology come to the fore.

\footnotetext{
${ }^{1}$ Ontology is the theory of being or existence. In anthropology, there has been a strong focus on epistemology or the theory of knowledge. The recent ontological turn in anthropology is "a methodological project that poses ontological questions to solve epistemological problems” (Holbraad and Pedersen 2017, 5, see also Henare, Holbraad, and Wastell 2007; Vigh and Sausdal 2014).
} 
We cannot and should not underestimate the diversity, alterity and variety, especially in cultural and social terms, that exist between different humans. Not everyone thinks, acts and lives as we do. Indeed, Gell states that "almost all behavior is, from somebody's point of view, 'apparently irrational'” (1998, 10). This often puzzling diversity continues to be anthropology's main preoccupation (see, for example, Henare, Holbraad, and Wastell 2007; Marcus 2008, 2). Sometimes anthropologists stress diversity and alterity so much that they neglect our shared humanity to the extent that some have questioned whether it is even possible to do anthropology. Such a position was voiced during the postmodern critique that affected anthropology (Clifford and Marcus 1986) and the more recent ontological turn (Vigh and Sausdal 2014, 54).

Dealing with human diversity has always been difficult. Emphasizing it at the cost of a common humanity, for example by valuing yourself over others, has regularly led to rejecting others, xenophobia and even denying the human status of others. Downplaying human diversity, on the other hand, can give the illusion that all humans form a happy family or others are really just like us. Ignoring or downplaying difference has never served us well. Therefore, the key to dealing with human commonality and diversity is not to see them as oppositions, but as dependent complements to each other. Being human is thus always being the same and different simultaneously.

As we begin to think anthropologically more purposefully, we need to center our thoughts on and around humans. In doing so we must keep peoples' commonality and diversity both in focus and in balance, neither neglecting nor emphasizing one over the other. This already is a big step towards thinking anthropologically and understanding what it is to be human in different places and relationships, and how we engage with the world around us.

\section{Culture and Society}

The notion of culture is arguably anthropology's biggest contribution to the wider world and if people have a vague idea about the discipline, then they often link it with culture. Having said this, within anthropology, the notion of culture continues to be widely debated and is much less established than it might appear. Indeed, culture is one of the more contentious topics and some anthropologists argue that it is not actually very helpful for studying what it is to be human. While I see their concerns, I tend to side with other contemporary anthropologists who continue to advocate its usefulness, at least when we pay close to attention to how we employ the notion (see, for example, Brightman 1995; Brumann 1999; Engelke 2018, 25-55; Rodseth 2018).
While culture has always been important in American anthropology, British anthropology pays more attention to the social side of the discipline. Society, or how humans organize themselves in various ways, therefore merits to be included by name in the discipline of anthropology (see, for example, Hendry 2016). Since the notion of society is more concrete than culture, it is also less controversial.

In this section I discuss what we need to understand by the complex and interdependent notions of both culture and society, which cover a wide range of human characteristics, including religion and language. I then discuss how we can apply the notions of culture and society to the study of humanity and how this contributes to thinking anthropologically.

People often talk about culture as if it were the object of anthropological study implying that we can get a good idea what the culture of, say, the English, really is. Popular books, such as Watching the English (Fox 2004), may reinforce the impression of the supposed existence of an English culture, which can then be demarcated from French culture, for example. This kind of thinking leads to a categorical separation of the two, thereby stressing their difference while neglecting human commonality. Culture-used in this way as a noun-becomes normative, or, as some anthropologists would say, hegemonic (Rodseth 2018). It easily stereotypes a certain group of people without being able to account sufficiently for its diversity. There are always people who deviate in various ways from normative "culture," for example through various issues of identity, including religious convictions. This easily leads to their stigmatization for no other apparent reason than for being different. Similarly, different socalled cultures have often been judged as more primitive or civilized. There is no lack of examples in recent history from slavery, colonization, the holocaust, genocide and wars more generally, that seek to save people from themselves by imposing so-called democracy and civilization (Engelke 2018, 56-82). This kind of thinking about "culture" usually proves to be disastrous for those concerned.

If we use the notion of culture as a noun and object of study, we are faced with three major questions: how do we demarcate one culture from another, how can we explain inconsistencies that usually exist within culture, and how can we account for cultural change and diversity without stigmatizing those who think or act differently? In contemporary anthropology we consider culture to be so complex, vague and dynamic that potential answers feel more rhetorical than valid. Following this line of argument, I agree with anthropologists like Engelke who state: "I can't offer you a pithy definition [of culture]” $(2018,25)$.

Practically, this means that we need to abandon the idea of culture as an all-encompassing, quantifiable and 
qualifiable object of anthropology. Rather, as I have already discussed above, anthropology studies what it is to be human, and here the question of culture has its place, not as a noun, but rather as an adjective (Engelke 2018, 51): Humans are cultural beings. It is thus not culture that defines human diversity, but rather our diverse ways of engaging with each other and the world around us that result in various cultural traits, which, in turn, manifest themselves as part of being human. The profusion of various cultural traits across humanity can thus better account for human diversity, while simultaneously maintaining humanity's commonality as cultural beings. Similarly-and here the question of society comes back in-humans are social beings and thus social traits are always part of what it is to be human too.

Take food, for example. All humans must eat if they want to live, so food is part of our commonality. When it comes to what, when, where, how and with whom we eat, and how we procure our food, however, various cultural and social traits begin to manifest themselves in force.

Various cultural and social traits, then, lie at the base of our always limited perspective that we acquire when growing up and that we continue to shape throughout our lives, and, in reverse, that shape our lives. Various cultural and social traits also underpin the way we perceive and interact with other humans and the world around us, which we always do through culturally and socially determined interpretation. Many cultural and social traits remain hidden from our consciousness and we often only become aware of some of them when we face people who have different cultural and social traits than ours. Various cultural and social traits also interact with how humans organize themselves socially in various groups and structures of power. It is thus the various cultural, social, religious, linguistic and other aspects of our lives and of being human that shape us as humans in all our diversity.

Thinking anthropologically begins with humans, notably by balancing both our commonality and diversity. As we learn to think anthropologically about human diversity, we should learn to become more inquisitive and ask why people are different or do things differently from others. There are usually cultural and social reasons why we find difference. Thinking anthropologically starts with the awareness of potential difference, followed by trying to figure out how and why such difference manifests itself, especially in cultural and social terms. Anthropology provides some valuable methods for this of which reflexivity is the most important and foundational one.

\section{Reflexivity}

Over the years, anthropology has developed a variety of methods such as participant observation and interviewing techniques (see, for example, Bernard 2018; Hammersley and Atkinson 2007). Such anthropological methods help us to learn more about humans especially when they are culturally and socially different. Knowing about these methods and how to apply at least some of them are central to learning to think anthropologically. Such methods help our anthropological thinking to become more systematic, thorough and above all more focused. Anthropological methods, however, are not always easy to apply and, more importantly, they never produce neat results. Rather, they need to be open by default as they enable us not only to capture what we might expect but more importantly, what we cannot anticipate or imagine (Holbraad and Pedersen 2017, 5). This means that anthropological methods are often messy, vague and not always easy to use. This may be the reason why some have tried to come up with simple tools, usually based on formulas, where you feed data in and answers come out. Such tools tend to focus on culture as a noun, which they oversimplify and treat as normative. They should thus be avoided. Anthropological methods, on the other hand, are powerful for achieving their purpose of studying humanity, or, as Malinowski put it in the language of his time, "to grasp the native's point of view, his relation to life, to realize his vision of his world" (1922, 25, emphasis in original).

Anthropologists widely accept that doing cultural and "[s]ocial research has to be an engagement, not an exercise in data collection" (Banks 2001, 179), requiring at least some personal investment. It is not enough to read what others have written, although this is always a good starting point. What is important for learning to think anthropologically, is to engage with our counterparts personally and learn from them in a more experiential way. Doing such research means in the first place that we enter into various relationships on which our research comes to depend. The quality of our relationships is directly linked to what we are able to learn from our counterparts, both in depth and breadth. Even from relatively new relationships, we can begin to learn a lot, but it can sometimes take many years for relationships to mature enough and for trust to grow before people really begin to open up in ways they could not do before. Long-term engagement with people, as has been typical for many missionaries (van der Geest 2011, 259), for example, is thus a huge asset for doing anthropology.

Anthropological methods start with relationships and engaging with other humans. Thanks to this, we ourselves are "the research instrument par excellence" (Hammersley and Atkinson 2007, 17), which requires "the full engagement of the whole person" (Merz and Merz 2017, 11). We thus need to pay as much attention to ourselves as we do to our counterparts and for this 
purpose, the method called reflexivity is the most foundational and significant one (see, for example, Evens, Handelman, and Roberts 2016; Foley 2002; Lichterman 2017; Salzman 2002). It is a relatively new method that was formulated in response to the postmodern critique in anthropology and the recognition that anthropologists themselves are humans with their own cultural and social perspectives and baggage. This, in turn, influences their thinking and behavior and thus affects the questions and results of their research as well as the way they present it. Anthropology cannot be an objective science. This recognition has led to the call for reflexivity in the sense that anthropologists need to think about and account for their own cultural and social backgrounds and how this influences the way they work. Accordingly, anthropologists have "to become much more reflexive about all ethnographic [and anthropological] practices -from field relations and interpretive practices to producing texts" (Foley 2002, 473, emphasis in original).

Since then, the idea of reflexivity has been cast much broader as a more general interpretive activity that underlies doing anthropology (Lichterman 2017). More importantly, reflexivity as thinking, and thinking about thinking, is now recognized as "an inherent feature of the experience of being human" (Evens, Handelman, and Roberts 2016, 2) and thus part of human commonality. Since reflexivity itself is a human phenomenon, it is always culturally and socially situated and thus needs to be included in our reflections (Evens, Handelman, and Roberts 2016). In this sense, reflexivity is the most foundational method that anthropology provides as we engage with other humans. It is also the most important approach to understanding cultural and social diversity by thinking about it and by thinking about how we and others think about it. It is not only an activity but more importantly an attitude that should underpin everything we do. Reflexivity thus lies at the heart of thinking anthropologically.

Anthropological reflexivity starts with the awareness that our own cultural and social backgrounds provide us with merely one perspective among many and that we sometimes find it hard to accept that other perspectives are equally valid and also have something valuable to contribute to humanity. A good place to begin such reflection could be to ask how much of what we understand about being a Christian (or indeed any other attribute that provides us with a sense of identity) is culturally and socially determined? By regularly questioning ourselves, and by learning from those who are different, we can discern how much of how we think, act, and live stems from our own cultural and social backgrounds, how much may be specific to our counterparts and what is common to both.

It is important that we seek to understand people as we find them and to make sense of how they think, act, and live both on their own terms and from their own perspectives. This means that we should not make assumptions about others on the basis of what we think we know about them. We also need to avoid as much as possible bringing our own thoughts, preoccupations, expectations and interpretations to the table and desist from judging those who are different. Being reflexive further helps us to do this.

We may not always agree with others and we certainly do not need to embrace everything unquestioningly. Indeed, anthropology demands that we keep a reflexive distance between ourselves and our counterparts. This idealistic call to comparative neutrality, worthy though it is, is largely unachievable, since we always evaluate and interpret what we experience by drawing on our cultural and social backgrounds. We cannot do otherwise. The experiences we have when we engage with our counterparts in various ways can be both exhilarating and unsettling, and they affect us in various ways, both positively and negatively. This, in turn, always feeds back into the way we think and continue to engage with humans who are different from us.

The purpose of reflexivity, then, is to untangle our views from the ones of our counterparts as much as possible. This often leaves us in a tension where different views are sometimes at odds, incongruous or even incommensurable (see, for example, Ewing 1994; McIntosh 2004). Together with Sharon Merz, I have called this ambiguous and plural position where the self meets the other the "ontological penumbra" (Merz and Merz 2017). It is a culturally and socially gray area that we come to occupy as humans both existentially and reflexively, as we engage with various counterparts. We can learn more about what it means to occupy the ontological penumbra through being reflexive, but anthropology does not give much advice when it comes to dealing with ambiguity and tension more existentially and thus personally.

In the end, being reflexive means that we need to reflect on our backgrounds and how these have shaped how we see ourselves and others, as well as how these views shape the way we relate to each other. The better we know ourselves as culturally and socially situated beings, the better we are positioned to understand others. In other words, not only must we keep an open mind towards those who are different, we also need to open ourselves up and be willing to learn from others.

Reflexivity, as presented so far, provides a method that comes out of human commonality and helps us to think about human diversity, notably our own cultural and social backgrounds in relation to the ones of our counterparts. Additionally, we need to be reflexive about sources we inevitably draw on to make sense of our counterparts, including various ideas and theories, 
be they anthropological or otherwise. Rynkiewich acknowledges: "There are no people on earth who are able to step completely outside their own culture in their evaluation of other people's ways-not even anthropologists, even though we try" $(2011,27)$.

An example concerns so-called honor/shame cultures. As I have already mentioned, it is problematic to classify "cultures" according to profiles of predetermined parameters, such as honor and shame, and separate them from others, such as guilt/justice cultures, whether we apply a categorical or a more graded distinction. We cannot assume that definitions established on and around the English words "honor" and "shame" are easily applicable to other societies without running the risk of generalizing, stereotyping and misrepresenting, even if original definitions are based on anthropological research (Engelke 2018, 8499; Herzfeld 1980, 84-99). It is certainly helpful to look at existing materials and ideas and engage with them reflectively, but we should never let them determine our understanding or override what we find when we engage with the people we seek to understand. This is why we need to reflect on various sources we draw on, including anthropological ones, and assess their suitability continuously, as we seek to understand our counterparts in their own terms.

I experienced this in my own research. When I tried to get my head around what I considered purely material things-such as stones-are for people in northwestern Benin, West Africa, I found my preconceived ideas wanting. Neither did existing anthropological theories of materiality suffice to account for what I observed (Merz 2017). Anthropological reflexivity proved key in solving this problem. I sought to understand how the people I worked with think and reason about themselves and the world around them while reflecting on myself and on existing theories. Through this reflexive process it became apparent that I had to use my findings and insights to alter theory, so that it could account for what I had come to understand (see also Henare, Holbraad, and Wastell 2007, 4).

Reflexivity, or the innate human faculty of thinking, and of thinking about thinking, is foundational and important to thinking anthropologically, which is to think about humans and all things cultural and social more methodically. Thinking anthropologically always starts with what we find in a given setting. Since new knowledge is only possible on the basis of what we already know, reflection on our prior knowledge, both our own and others, is crucial in becoming more proficient in thinking anthropologically. Reflexivity, then, is a three-way activity. It is the study of others and the reflection on the self in light of other sources and anthropological work.

While reflexivity is the most foundational method that helps us think anthropologically, it is also the most challenging. It relies on abstract thought and introspection, and it requires us to learn to live with cultural and social tension at least to some degree. An important question that should never evade reflexivity is our motivation of engaging with theology and missiology, especially from a Christian perspective. The next area I explore is how Christianity, theology and mission relate to thinking anthropologically and how these areas can contribute towards it.

\section{Anthropology and Christianity}

The relationship between anthropology and Christianity has been rocky, as I have already indicated in the introduction. This has not always been the case. In the history of anthropology, Christian missionaries played a crucial role in establishing the ethnographic focus of the new academic discipline (Burton and Burton 2007, 210). Many missionaries provided early anthropologists with valuable data, some have written now classic ethnographic monographs, a few had fruitful academic careers as anthropologists. Today, many continue to provide crucial support for anthropologists as they conduct their fieldwork (Burton and Burton 2007; Higham 2003; Pels 1990; Whiteman 2003). Van der Geest has further argued that missionaries are not actually much different from anthropologists in that they are both interested in cultural difference "by understanding it in terms of their own beliefs" (1990, 593).

In the wake of many colonies becoming independent in the 1950s and 1960s, anthropologists started to look at the impact of the colonial heritage, which included Christian mission. While they approved of the new political independence, they were skeptical about the continued presence and work of foreign missionaries. This raised a new anti-mission sentiment among secular anthropologists and some started to accuse mission organizations of continued imperialism, ignoring the fact that many of the fighters and leaders of independence had been educated in mission schools.

By the 2000s, once the wave of the postmodern critique had washed over anthropology, its relationship with Christianity began to relax again. By then it had become evident that while Christianity was in decline especially in Europe, it experienced an unanticipated growth in many other parts of the world (Jenkins 2002). Among anthropologists, Christianity could no longer be seen as a Western religion that missionaries tried to force on others. Rather they were now faced with the question of why others actually embraced it and adapted it to their own cultural and social settings and preoccupations. Accordingly, world Christianity has since become a valid topic of anthropological inquiry, notably under the label of the "anthropology of Christianity” (see, for example, Bialecki, Haynes, and 
Robbins 2008; Jenkins 2012; Robbins 2014, 2018).

A further development was that anthropologists recognized and now acknowledge that some of the most influential anthropologists either had a Christian background, which they rejected, or were practicing Christians (Engelke 2002; Larsen 2014). This demonstrates that it is not only anthropologists with an explicit secular background-which has been the unspoken norm for a long time-who can make valid contributions to the discipline. Since anthropology focuses on human diversity, we must promote a diversity of cultural and social perspectives in anthropology itself, including anthropologists who share various religious and spiritual backgrounds. What is important is that anthropologists reflect on their backgrounds and biases regardless of their religious or secular stance (Merz and Merz 2017).

When it comes to Christianity, it could be argued that Christians make good anthropologists. Many anthropologists who are Christians today are in one way or another part of minority groups. This has become a default position in most parts of the West, while nonWestern Christians are often part of minority groups because of their religious and/or ethnic identities. Being part of a minority group often makes people more aware of cultural and social differences and there will be always some who reflect on these more actively. It cannot be a coincidence that many of the early anthropologists came from Jewish or immigrant backgrounds (Eriksen 2006, 26). Furthermore, Christians who want to become successful academic anthropologists often need to reflect more on their backgrounds and must justify themselves more than those who have come from mainstream secular backgrounds. In light of the importance of reflexivity, this puts Christians in a potentially advantageous position as they have to engage with the discipline more thoroughly.

Lastly, Jesus Christ and Paul, on whose thought and teaching Christianity builds, can be seen as forerunners and practitioners of thinking anthropologically. Both lived in culturally and socially diverse societies and regularly engaged with people different from their own Jewish cultural and social backgrounds. Reflecting on the biblical accounts when faced with today's life can heighten Christians' awareness of various issues that are relevant to learning to think anthropologically, such as how to deal with human commonality in the face of cultural, social and linguistic diversity.

In the next three subsections I discuss first how Christianity has an affinity with thinking anthropologically and how it has dealt with cultural and social diversity from its beginning. Theology also makes an important contribution to thinking anthropologically by adding a spiritual and religious dimension, which-for the purpose of this article-is distinctly Christian.
Missiology, which I discuss in the last subsection, is the application of such a theologically engaged anthropology. This means that anthropology and theology need to work together to further our ability to think anthropologically in a missiologically engaged way.

\section{Thinking Anthropologically in Christianity}

Jesus was always sensitive to his surroundings and he showed empathy and compassion towards the people he encountered, which included the marginalized and stigmatized. He never attacked, judged or condemned people for being different in either cultural, social or linguistic terms, but he regularly challenged his counterparts of various backgrounds for failing to live and act according to his teachings. The core of Jesus' ethics is based on nonviolence and dialogue, and of empathy, compassion and love towards others, including those who are different and even enemies. This continues to pose a big challenge not only to Christians, but also to those who think anthropologically. Similarly, the later theological formulation of the idea of Jesus' incarnation, of God becoming man, may not be easy to accept in secular anthropological terms, but it takes the idea of participant observation to a level which anthropologists can only dream about (see also Arnold 2006, 274; Backues 2017).

As Jesus' teachings started to spread beyond Judaism, questions of cultural and social identity came to the fore, leading to tensions. At the council of Jerusalem (Acts 15:1-21, see also Walls 1996, 7-8), the decision was reached that people did not need to be circumcised-and thus accept a Jewish identity-before they became Christians. Christianity was thus established as being open to cultural and social expressions other than Judaism on whose basis it was first formulated. After all, God is the creator of all people in all their cultural and social diversity and not only of Jews or Christians. This implies that while Christianity established itself as common to all humans, it was equally recognized that it is always culturally and socially situated, and thus diverse.

We need to remind ourselves that Christianity started as a movement, rather than a normative or hegemonic religion that came to be closely associated with European culture. During the first centuries, it regularly crossed cultural, social and linguistic boundaries. New Testament passages, such as Acts (2:1-13) and Revelations (7:9) or the fact that we have four sometimes different accounts of the life of Jesus, indicate that early Christians affirmed and even embraced linguistic and cultural diversity. It further seems significant that Jesus' Aramaic words were never fixed, but first put in writing in Greek. As Sanneh (2009) has argued, Christianity is by default translated. Today it is widely recognized that world Christianity itself is so 
diverse that its commonality can be questioned (Walls 1996). And yet, Christians seek to hold on to their unity in all its diversity. This is why we must guard ourselves against valuing certain culturally and socially situated Christian traditions or expressions above others. I am convinced that while all Christians have something valuable to contribute to world Christianity, we equally all have blind spots and weak areas, both in our lives and in our Christian backgrounds and expressions. This is why we should be open to learn from others.

Studying the lives and work of Jesus and Paul can give us insights into what it means to think anthropologically not only in terms of human commonality and cultural and social diversity, but also concerning anthropological methods, such as reflexivity. Beyond being able to think anthropologically, Jesus and Paul both had clear theological interests. Since anthropology has a history of friction with Christianity, its relationship with theology has been at best awkward (Merz and Merz 2017; Robbins 2006). Recent years, however, see an increasingly fruitful dialogue (see, for example, Lemons 2018; Meneses and Bronkema 2017).

\section{Thinking Anthropologically for Theology}

Theology, or the study of God, has always shared some key similarities with anthropology, notably in terms of human commonality and diversity (Larsen and King 2018), even though it maintains a different focus. Like anthropologists, theologians study what it is to be human, but with a special focus on God and the relationship they have with Him. Thus, while humans stand central in theology too, God comes first. From a more anthropological perspective, I join Haynes who views "theology as a particular kind of reflexive action, aimed at understanding who God is, how he works in the world, how people ought to relate to God, and what they can expect from him" $(2018,266)$.

Another difference is that anthropology focuses on learning how humans perceive the spiritual or lessvisible parts of the world and how they interact with it, while theology goes beyond this. Theologians also study the character of God and how humans should relate to Him. In doing so they pay attention to the reliability and veracity of religious thought, as well as potential pitfalls. Theology often provides culturally dependent conventions that help draw the line between what can be considered Christian or not. This, in turn, relies on theologians' evaluation, judgement and reflexively done in due humility (Backues 2017; Robbins 2018, 238, 240-242). In order to do this well, theologians should also pay attention to cultural and social expressions of the people they do theology for and with.

Thinking anthropologically can help theology to address and reflect on such questions of the cultural and social aspects of Christianity more thoroughly, as it focuses on human commonality and diversity, especially in cultural and social terms. The distinction between what is Christian and what is cultural is far from clear cut. Essentially, in view of the sheer diversity within world Christianity itself, not much remains that can be called "Christianity" when stripped of its cultural and social aspects. Walls (1996, 11-12) considers that what holds world Christianity together is the person of Jesus Christ as revealed in the Bible. Christian theology should thus start with this as its core and build on and around it. In doing so, we should think anthropologically and thus always consider cultural and social factors.

For example, most theologians would agree that celebrating the Lord's Supper is important for Christians. It is a practice that Jesus modelled and asked his followers to do in remembrance of him. Hence, it has become part of most Christian traditions in one way or another. What exactly the Lord's Supper is, what it means and how it is labeled depends largely on denominational traditions and thus on cultural and social conventions. When it comes to the more practical aspects, we can observe an equal diversity, for example in how often it is done, which words should be pronounced, what form it takes and what kind of food items are offered. What people consider to be Christian is usually not only biblically and theologically determined, but always also by their cultural and social settings. Many of these ideas and practices may not have much of a theological function, but rather serve as markers of identity which serve to demarcate a Christian community from other denominations and other faiths. Although this can be seen as a challenge to Christian unity, thinking anthropologically can help us learn to understand and even appreciate Christian diversity, since each unique perspective can contribute something to wider theology that other perspectives cannot.

We need to guard ourselves from viewing our preconceived and perspectival Christian and theological notions, which includes how we interpret and understand the Bible, as either better than others or normative by default. Richards and O'Brien remind us: "The trouble is, what is 'proper' by our standards-even by our Christian standards-is as often projected onto the Bible as it is determined by it" $(2012,33)$. Whatever stance we take on the inspiration of the Bible, its books have been written over many hundreds of years by cultural and social beings. Accordingly, there is no such thing as a biblical culture, rather when we read the Bible from an anthropological perspective, we encounter many different cultural and social settings and expressions. For example, the Hebrew nomad Abraham lived in a very different world to town dwelling Roman centurion Cornelius, one of the first non-Jewish Christians. This means that not only do we 
need to reflect about ourselves and our theological backgrounds, but also consider the different cultural and social settings we find in the biblical accounts (for the New Testament see, for example, Bailey 2008; Bell 1998). Reading the Bible while thinking anthropologically gives us a deeper understanding of what the texts may have meant for their original audiences. This helps us to reflect on the important question of what in the biblical texts is specific to cultural and social settings, what applies more widely and what provides underlying principles that can then work themselves out in a variety of cultural and social expressions. In doing so it is important that we consider the whole of Jesus' teaching as a guideline.

Thinking anthropologically for theology, therefore, not only includes thinking about our own and our counterparts' cultural and social backgrounds and theological ideas, but also includes the various cultural and social settings found in the Bible. Thinking anthropologically is thus foundational to theology. At the same time, anthropology can benefit from theology by drawing on its religious and spiritual expertise, thus enabling us to go beyond the limits of the discipline.

Contrary to much of anthropology, especially in its secular expression, theology affirms the idea of the agency of God and a spiritual realm in some way (Bronkema 2017; Haynes 2018, 278-279; Merz and Merz 2017, 12-13). Theology thus allows us to include God and the spiritual realm in our reflections on our religious and spiritual backgrounds, as we engage with our counterparts. This comes with two main advantages. Firstly, we can accept religious beliefs and practices for what they are for the people we study, rather than reducing them to a social function of social or human agency, or some kind of illusion, as secular anthropologists often view it (Merz and Merz 2017, 34). This means that theology can contribute to anthropology's goals of studying what it is to be human, also in religious and spiritual terms, by seeking to understand the way that others see themselves.

Secondly, theology can provide us with a basis to deal with the spiritual and religious questions that confront us during our encounters. As I explained above, reflexivity and anthropological thinking often create a tension between our own perspectives and those of our counterparts. This can happen, for example, when we find it difficult to accept other people's views or practices, even after having sought to understand them from their perspective. How far should we get involved and how far do we want to participate in practices that seem contrary to deep convictions or that potentially appear detrimental to our spiritual health and lives? These are questions that all anthropologists face, whether they have more spiritual or more humanist orientations (McIntosh 2004; Merz and Merz 2017; Stoller and Olkes 1987). I am not prepared to give concrete answers to such questions here, since we are all different and react differently to cultural, social and religious diversity. What I do propose is that reflexivity is key to addressing such questions and drawing on theology can significantly contribute a specifically Christian perspective.

A starting place for integrating theological ideas with anthropology is the ontological penumbra (Merz and Merz 2017, see also above), which is the culturally and socially ambiguous space of dialogue, encounter and engagement that we access thanks to the humanity we share with others. Bringing theology to the ontological penumbra means going beyond our human counterparts by including God and other non-human beings as described in the Bible. God can thus provide us with a relational anchor to hold onto. We need to bear in mind, however, that even though we consider God to be beyond humanity, the way we experience Him remains culturally and socially situated. Bringing theology to thinking anthropologically may not always diminish the tensions we may feel as we occupy the ontological penumbra, but I think it gives us a tool to address and tackle such tensions in a way anthropology cannot.

None of us, including anthropologists and theologians, can ever stop being cultural and social beings. Often our counterparts do not expect us to agree with everything they say and do. They recognize, just as we do, that there are differences among humans and usually allow others to have their own opinions and perspectives as well. In my experience, this has hardly ever affected my engagements with others, provided I try to think anthropologically by maintaining a humble, open and empathic attitude towards them.

Theology is important for thinking anthropologically about humans and their cultural and social diversity, as it adds a spiritual and religious dimension, which in our case is explicitly Christian. This is particularly important as we move from theology to missiology with its practical focus of applying theology and anthropology to making God's Word more widely available.

\section{Thinking Anthropologically for Missiology}

Missiology, or the study of mission, has been even more contentious in anthropology than Christianity and theology, mainly because of Christianity's identification with European cultural expression and mission's association with colonialism. Today, most anthropologists recognize that people and groups of people must have an integrity that is part of being human that enables them to decide for themselves what they accept and reject when they come into contact with others such as missionaries, anthropologists, traders or government representatives. I have heard many African Christians 
express their deep gratitude towards the missionaries who came to their ancestors and sometimes sacrificed their lives to do so, but I am yet to hear people talk in similar terms about anthropologists.

Missiology seeks to apply both anthropology and theology to communicate the biblical message in a relevant and accessible way, also counting on God to do His part in this process. Communicating and sharing God's Word with others has been at the heart of Christianity since Jesus taught his disciples, but the question, which is foundational to missiology, is how exactly do we do it?

My experience of missionaries has been that although they do engage in missiology, their view of mission is often strongly influenced by their specific Christian-and thus cultural and social-backgrounds. Accordingly, I find that specific theological convictions and traditions about mission, including different views of eschatology, continue to be the main driving factors in mission practice. Also, there are wider cultural beliefs and practices shared beyond Christianity that influence mission, such as neoliberal capitalism. Funding mission, for example, is often driven by concrete results and hardly by questions of quality, sustainability, local ownership or processes that account for cultural and social specifics.

Missiologists regularly drew on anthropology up to the 1980s. Many then became more reluctant to do so in the face of the postmodern critique prevalent in anthropology. Today, many missionaries do not see value in anthropology anymore and reject it as either unnecessary or costly. Whiteman lamented that "many, if not most, missionaries are not anthropologically minded" (2003, 402). Although ideas about culture as a noun remain part of missiology, missionaries continue to use the notion of culture to objectify and classify difference, rather than thinking anthropologically. They thereby accept the challenge of cultural difference while reducing it to predetermined types or generalizing profiles, such as honor/shame, that limit the need to engage with those who are different (see above).

On the other hand, anthropology and thinking anthropologically for the theologically and missiologically engaged starts with real people. It seeks to focus on learning about cultural and social diversity in terms of how people see themselves and how they think, act, and live, including the possibility of discovering what we cannot anticipate or imagine. In doing so we can draw on what we already know and what others have done by being reflexive and by focusing on specific cultural and social settings.

Missiology needs to renew its engagement with contemporary anthropology (see, for example, Rynkiewich 2011) and get its head around what it means to think anthropologically as a basis for all missiological reflection and activity. Thinking anthro- pologically about mission means that we start with humans, just as Jesus Christ and Paul have done, and be open to what we cannot anticipate beforehand. We need to gain a deep anthropological understanding of how people think, act, and live in all their cultural, social and linguistic diversity. More often than not, this also means learning to live in the tension that human commonality and diversity creates, as we seek to relate to and engage with them, both sharing with them and learning from them. We can realistically only hope for change in those we encounter if we humble ourselves and make ourselves vulnerable to being changed ourselves. Mission should not be so much a presentation of Christianity and how it is practiced than a reflexive dialogue with others in which we seek to help each other to draw closer to God. If people learn about Christianity, then it is not by simply accepting a message, but by a deep engagement not only with the message but also with the messenger.

In 1 Corinthians, Paul gives us an idea about his approach to mission: "Though I am free and belong to no one, I have made myself a slave to everyone, to win as many as possible" (9:19), which, as we read on, includes all people of all faiths. In my experience and contrary to Paul, many missionaries have been hesitant to really engage with other people, especially those who do not share their faith. Whiteman "admit[s] that, in over 30 years of studying missionaries, I have yet to find anyone who "went too far"” (2003, 409).

Missionaries must think more anthropologically in the way I have presented in this article. Thinking anthropologically provides not only tools, but above all an attitude towards cultural and social diversity, that can help them to improve their multicultural and multireligious engagements. Theology plays a role in this by providing a means to reflect on religious and spiritual issues, especially in light of the person of Jesus and the biblical account that culminates in his life, death and resurrection. In this sense, theology is indispensable to missiology for keeping the veracity of the message in focus and helping to provide good and appropriate teaching, especially when it accounts for specific cultural and social settings.

Missiology, then, should study others and reflect on the self in light of Christianity's core message of Jesus Christ and the Bible. Missiology should thus bring anthropology and theology together in a practical way by engaging with counterparts in various ways and provide ideas for people's preoccupations while diminishing the risk of rejection and miscommunication. In other words, thinking anthropologically should be the starting point for all missiological reflection and activity. 


\section{Conclusion}

Thinking anthropologically is putting humans at the center by asking what it is to be human in different places and relationships, and how we engage with the world around us. Thinking anthropologically is keeping human commonality and our immense cultural and social diversity in balance. Thinking anthropologically is learning to be reflexive by thinking about cultural and social diversity and thinking about the way we think from our own cultural and social backgrounds. Finally, thinking anthropologically is learning to apply anthropological methods that help us to learn more about others and how they think, act, live and how they understand life themselves.

While academic anthropology serves as its backbone, the ability to think anthropologically and having an anthropological attitude are more fundamental and broader than the discipline. You do not need to become a fully-fledged anthropologist to think anthropologically; other academic disciplines and the life experiences of people who are different also have something to contribute.

Anthropology is limited in its ability to sufficiently address tensions that arise through our engagement with those who are different from us, especially when it comes to spiritual and religious expressions. So, when we are faced with such questions as we seek to engage with others, theology can provide a perspective that acknowledges the agency of God and of other beings of the spiritual realm. On the other hand, thinking anthropologically about theology reminds us that ideas about God, the Bible and theology itself are always culturally and socially situated.

In moving to missiology, thinking anthropologically should provide the starting point for all missiological reflection and activity. We can only expect people to change if we too, are open to change by humbling ourselves and making ourselves vulnerable. This is best done through a reflexive dialogue with others in which we seek both to give and to take.

Thinking anthropologically should become an attitude that we apply without always having to make a conscious effort to think about it. We learn it best by doing. It should not take long before you begin to see that thinking anthropologically affects the way you think and look differently at other people and the world. As you apply the method of reflexivity you should become aware of such a change. For example, at the end of a two-week anthropology course, one of the students commented: "You know, before studying anthropology I thought that the people I'm working with were wrong. But know I've come to understand that they're simply different."

Learning to become proficient in thinking anthropologically should have an impact on our lives.
Hendry has observed that her "students . . . often proclaim that anthropology has come to change their lives in a profound and irreversible way" $(2016,1)$. Anthropology and thinking anthropologically have the potential to add to the quality of life and work as we engage with others, however similar or different they appear to us. By better understanding those who surround us, we will find it easier to appreciate them and to work together with them. Whenever we are faced with other humans, our attitude and ability to think anthropologically will be a tremendous asset.

\section{References}

Arnold, Dean E. 2006. Why are there so few Christian Anthropologists? Reflections on the Tensions between Christianity and Anthropology. Perspectives on Science and Christian Faith 58 (4): 266-282. http://www.asa3.asa3online.org/ASA/PSCF/2006/PSCF12 -06Arnold.pdf. Accessed 28 October 2014.

Backues, Lindy. 2017. Humility: A Christian Impulse as Fruitful Motif for Anthropological Theory and Practice. In On Knowing Humanity: Insights from Theology for Anthropology. Eloise Meneses and David Bronkema, eds. Pp. 101-136. London: Routledge.

Bailey, Kenneth E. 2008. Jesus Through Middle Eastern Eyes: Cultural Studies in the Gospels. Downers Grove, IL: IVP Academic.

Banks, Marcus. 2001. Visual Methods in Social Research. London: SAGE Publications.

Bell, Albert A. Jr. 1998. Exploring the New Testament World: An Illustrated Guide to the World of Jesus and the First Christians. Nashville, TN: Thomas Nelson Publishers.

Bernard, H. Russell. 2018. Research Methods in Anthropology: Qualitative and Quantitative Approaches, sixth edition. Lanham, MD: Rowman \& Littlefield.

Bialecki, Jon, Naomi Haynes, and Joel Robbins. 2008. The Anthropology of Christianity. Religion Compass 2(6): 1139-1158.

Bowman, Glenn. 1997. Identifying Versus Identifying with "the Other": Reflections on the Siting of the Subject in Anthropological Discourse. In After Writing Culture: Epistemology and Praxis in Contemporary Anthropology. Allison James, Jenny Hochey, and Andrew Dawson, eds. Pp. 34-50. London and New York: Routledge.

Brightman, Robert. 1995. Forget Culture: Replacement, Transcendence, Relexification. Cultural Anthropology 10(4): 509-546. 
Bronkema, David. 2017. Principalities: Insights from Practical Theology for a Transformed Applied Anthropology. In On Knowing Humanity: Insights from Theology for Anthropology. Eloise Meneses and David Bronkema, eds. Pp. 165-174. London: Routledge.

Brumann, Christoph. 1999. Writing for Culture: Why a Successful Concept Should Not be Discarded. Current Anthropology 40: S1-S27.

Burton, John W. and Orsolya Arva Burton. 2007. Some Reflections on Anthropology's Missionary Positions. Journal of the Royal Anthropological Institute (N.S.) 13(1): 209-217.

Clifford, James and George E. Marcus, eds. 1986. Writing Culture: The Poetics and Politics of Ethnography. Berkeley, CA: University of California Press.

Engelke, Matthew. 2002. The Problem of Belief: EvansPritchard and Victor Turner on "the Inner Life". Anthropology Today 18(6): 3-8.

_ 2018. How to Think Like an Anthropologist. Princeton, NJ: Princeton University Press.

Eriksen, Thomas Hylland. 2006. Engaging Anthropology: The Case for a Public Presence. Oxford: Berg.

- 2010. The Challenges of Anthropology. International Journal of Pluralism and Economics Education 1(3): 194202.

Evens, Terry, Don Handelman, and Christopher Roberts. 2016. Introduction: Reflexivity and Selfhood. In Reflecting on Reflexivity: The Human Condition as an Ontological Surprise. Terry Evens, Don Handelman, and Christopher Roberts, eds. Pp. 1-20. New York: Berghahn Books.

Ewing, Katherine P. 1994. Dreams from a Saint: Anthropological Atheism and the Temptation to Believe. American Anthropologist 96(3): 571-583.

Foley, Douglas E. 2002. Critical Ethnography: The Reflexive Turn. International Journal of Qualitative Studies in Education 15(4): 469-490.

Fox, Kate. 2004. Watching the English: The Hidden Rules of English Behaviour. London: Hodder \& Stoughton.

Gell, Alfred. 1998. Art and Agency: An Anthropological Theory. Oxford: Oxford University Press.

Hammersley, Martyn, and Paul Atkinson. 2007. Ethnography: Principles in Practice, third edition. London: Routledge.

Haynes, Naomi. 2018. Theology on the Ground. In Theologically Engaged Anthropology: Social Anthropology and Theology in Conversation. Derrick J. Lemons, ed. Pp. 266-279. Oxford: Oxford University Press.
Henare, Amiria, Martin Holbraad, and Sari Wastell. 2007. Introduction: Thinking Through Things. In Thinking Through Things: Theorising Artefacts Ethnographically. Amiria Henare, Martin Holbraad, and Sari Wastell, eds. Pp. 1-31. London: Routledge.

Hendry, Joy. 2016. An Introduction to Social Anthropology: Sharing our Worlds, third edition. London: Palgrave.

Herzfeld, Michael. 1980. Honour and Shame: Problems in the Comparative Analysis of Moral Systems. Man (N.S.) 15(2): 339-351.

Higham, C. L. 2003. Saviors and Scientists: North American Protestant Missionaries and the Development of Anthropology. Pacific Historical Review 72(4): 531-559.

Holbraad, Martin and Morten A. Pedersen. 2017. The Ontological Turn: An Anthropological Exposition. Cambridge: Cambridge University Press.

Jenkins, Philip. 2002. The Next Christendom: The Coming of Global Christianity. Oxford: Oxford University Press.

Jenkins, Timothy. 2012. The Anthropology of Christianity: Situation and Critique. Ethnos 77(4): 459-476.

Larsen, Timothy. 2014. The Slain God: Anthropologists and the Christian Faith. Oxford: Oxford University Press.

Larsen, Timothy and Daniel J. King. 2018. The Dependence of Sociocultural Anthropology on Theological Anthropology. In Theologically Engaged Anthropology: Social Anthropology and Theology in Conversation. Derrick J. Lemons, ed. Pp. 50-65. Oxford: Oxford University Press.

Lemons, Derrick J., ed. 2018. Theologically Engaged Anthropology: Social Anthropology and Theology in Conversation. Oxford: Oxford University Press.

Lichterman, Paul. 2017. Interpretive Reflexivity in Ethnography. Ethnography 18(1): 35-45.

Malinowski, Bronislaw K. 1922. Argonauts of the Western Pacific. London: Kegan Paul.

Marcus, George E. 2008. The End(s) of Ethnography: Social/Cultural Anthropology's Signature Form of Producing Knowledge in Transition. Cultural Anthropology 23(1): 1-14.

McIntosh, Janet. 2004. Maxwell's Demons: Disenchantment in the Field. Anthropology and Humanism 29(1): 63-77.

Meneses, Eloise, and David Bronkema, eds. 2017. On Knowing Humanity: Insights from Theology for Anthropology. London: Routledge. 
Merz, Johannes. 2017. Making Meaning Present: Semiotics and the Ontological Life of Stones in West Africa. Studies in Media and Communication 5(2): 145-156. http://redfame.com/journal/index.php/smc/article/view/27 58. Accessed 21 November 2017.

Merz, Johannes and Sharon Merz. 2017. Occupying the Ontological Penumbra: Towards a Postsecular and Theologically Minded Anthropology. Religions 8: article 5. http://www.mdpi.com/2077-1444/8/5/80. Accessed 28 April 2017.

Pels, Peter. 1990. Anthropology and Mission: Towards a Historical Analysis of Professional Identity. In The Ambiguity of Rapprochement: Reflections of Anthropologists in their Controversial Relationship with Missionaries. B. Bonsen, H. Marks, and J. Miedema, eds. Pp. 77-100. Nijmegen: Focaal.

Richards, E. Randolph, and Brandon J. O’Brien. 2012. Misreading Scripture with Western Eyes: Removing Cultural Blinders to Better Understand the Bible. Downers Grove, IL: IVP Books.

Robbins, Joel. 2006. Anthropology and Theology: An Awkward Relationship? Anthropological Quarterly 79(2): 285-294.

—_. 2014. The Anthropology of Christianity: Unity, Diversity, New Directions: An Introduction to Supplement 10. Current Anthropology 55(S10): S157S171.

- 2018. World Christianity and Reorganizing Disciplines: On the Emerging Dialogue between Anthropology and Theology. In Theologically Engaged Anthropology: Social Anthropology and Theology in Conversation. Derrick J. Lemons, ed. Pp. 226-243. Oxford: Oxford University Press.

Rodseth, Lars. 2018. Hegemonic Concepts of Culture: The Checkered History of Dark Anthropology. American Anthropologist 120(3): 398-411.

Rynkiewich, Michael A. 2011. Soul, Self and Society: A Postmodern Anthropology for Mission in a Postmodern World. Eugene, OR: Cascade Books.

Salzman, Philip Carl. 2002. On Reflexivity. American Anthropologist 104(3): 805-811.

Sanneh, Lamin. 2009. Translating the Message: The Missionary Impact on Culture, second edition, revised and expanded. Maryknoll, NY: Orbis Books.

Stoller, Paul, and Cheryl Olkes. 1987. In Sorcery's Shadow: A Memoir of Apprenticeship among the Songhay of Niger: Chicago: The University of Chicago Press.

van der Geest, Sjaak. 1990. Anthropologists and Missionaries: Brothers under the Skin. Man (N.S.) 25(4): 588-601.

- 2011. Shifting Positions between Anthropology, Religion and Development: The Case of Christianity. Exchange 40(3): 257-273.
Vigh, Henrik Erdman, and David Brehm Sausdal. 2014. From Essence Back to Existence: Anthropology Beyond the Ontological Turn. Anthropological Theory 14(1): 4973 .

Walls, Andrew F. 1996. The Gospel as Prisoner and Liberator of Culture. In The Missionary Movement in Christian History: Studies in the Transmission of Faith. Andrew F. Walls, ed. Pp. 3-15. Maryknoll, NY: Orbis Books.

Whiteman, Darrell L. 2003. Anthropology and Mission: The Incarnational Connection. Missiology: An International Review 31(4): 397-415.

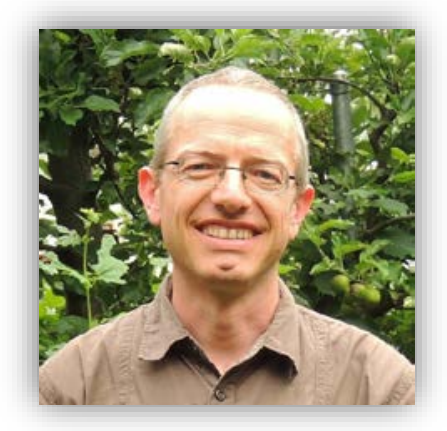

Johannes Merz is an anthropology consultant with SIL International. He has a PhD in cultural anthropology from Leiden University, the Netherlands. Johannes is also a visiting lecturer in anthropology at Redcliffe College in Gloucester, UK and the Theological College of Northern Nigeria in Jos, Nigeria. His main areas of interests include various aspects of religion and media.

Author email: johannes_merz@sil.org 